Cornell Law Library

Scholarship@Cornell Law: A Digital Repository

Cornell Law Faculty Publications

Faculty Scholarship

$1-1-2004$

\title{
On International and Interdisciplinary Legal Ethics Scholarship
}

W. Bradley Wendel

Cornell Law School, bradley-wendel@lawschool.cornell.edu

Follow this and additional works at: http://scholarship.law.cornell.edu/facpub

Part of the Comparative and Foreign Law Commons, Ethics and Professional Responsibility Commons, Jurisprudence Commons, and the Legal Profession Commons

\section{Recommended Citation}

Wendel, W. Bradley, "On International and Interdisciplinary Legal Ethics Scholarship" (2004). Cornell Law Faculty Publications. Paper 481.

http://scholarship.law.cornell.edu/facpub/481

This Article is brought to you for free and open access by the Faculty Scholarship at Scholarship@Cornell Law: A Digital Repository. It has been accepted for inclusion in Cornell Law Faculty Publications by an authorized administrator of Scholarship@Cornell Law: A Digital Repository. For more information, please contact jmp8@cornell.edu. 


\title{
Book Review
}

\author{
Editorial
}

\section{On International and Interdisciplinary Legal Ethics Scholarship}

\author{
W. BRADLEY WENDEL*
}

"Legal Ethics is an international and interdisciplinary journal dedicated to the field of legal ethics." The mission statement of this journal poses three concise challenges for scholars in this discipline: To define the domain of legal ethics, to study it from a perspective that is valid across jurisdictional boundaries, and to incorporate the insights of related disciplines. As befits an emerging and exciting field, lawyers and university faculty throughout the Englishspeaking common-law world have begun to engage with all three of these problems. The book reviews section of Legal Ethics has highlighted the publication of many of the most important works to emerge in the past decade. I look forward to continuing this tradition, while continuing to expand the international and interdisciplinary focus of the journal. As an initial editorial act, this brief essay reviews the landscape of legal ethics scholarship in the intersections of multiple jurisdictions and intellectual traditions, and offers some predictions about future developments in the literature.

\section{Legal Ethics as an Essentially Contested Concept.}

Legal ethics sometimes suffers from a kind of identity crisis. Suppose the question is whether some practice, such as contingent-fee financing of litigation, multidisciplinary practices, or concurrent representation of clients with differing interests is "ethical". What is this debate about? Strange as it may seem to someone unacquainted with the field, there is not an easy answer to that question. The reason for this is that legal ethics is an essentially contested concept, ${ }^{1}$ in the sense that there is no widely shared agreement on the subject to which the term refers. Legal ethics could be regarded as a subdiscipline of academic moral philosophy, so that an ethical question pertaining to lawyers' conduct would be resolved by appealing to

* Associate Professor of Law, Cornell Law School.

1 W. B. Gallie, "Essentially Contested Concepts", (1956) 56 Proceedings of the Aristolelian Sociely 167. 
notions such as consequences, rights, duties, and virtues. ${ }^{2}$ Alternatively, legal ethics could be understood in a somewhat less rigorous way, as the study of the traditions, norms, and etiquette of practicing lawyers. At best, this kind of analysis can make use of the tools of the empirical social sciences to develop rich accounts of law in action. ${ }^{3}$ Most commonly, the ethical question is understood in terms of whether the positive-law rules governing lawyers' conduct actually permit such an activity. In that case, the discussion would be an exercise in legal interpretation. The interpretive exercise quickly becomes complicated, however, by the variety of sources of regulatory authority that bear on lawyers' activities.

A common usage of the term "legal ethics" in the United States, and in other common-law countries as well, is to refer to the disciplinary codes established and enforced by the organised bar. In the US these are adopted by the highest courts of the states, generally following models developed by the American Bar Association, and enforced through administrative proceedings under power delegated by the highest courts. In the UK, the Bar and the Law Society make rules and quasi-official agencies like the Office for the Supervision of Solicitors impose sanctions for their violation. In most countries, however, the internal regulatory structure of the legal profession is only one of several constraints on lawyers' conduct. Regulation of American lawyers, for example, is strikingly polycentric, with several overlapping (and sometimes competing) sources of regulation. ${ }^{4}$ Lawyers must not only comply with disciplinary rules, but must also worry about civil liability for negligence, breach of fiduciary duty, and breach of contract, and even criminal liability for offenses such as perjury, obstruction of justice, and mail fraud. Attorneys who represent clients in litigated matters are subject to regulation by trial courts, pursuant to their inherent powers. For this reason, court-administered remedies such as disqualification, preclusive sanctions, and fee-shifting are responsible for much of the law governing attorney conflicts of interest, regulation of frivolous litigation, and other forms of litigation misconduct such as $e x$ parte contact with other represented parties. In addition, administrative agencies regulate specialist bars, such as securities and tax practitioners. Rather than speaking of the regulation of the legal profession as legal ethics, it is more appropriate to think in terms of the law governing lawyers. Indeed, the American Law Institute recently issued a comprehensive summary of this field, entitled the Reslatemen of lhe Lam Governing Lamyers.

The Restatemenl project has drawn attention in the US to the multilayered regulation of the legal profession and its attendant complexities. Many student casebooks and practitioner-oriented treatises now take a comprehensive law-of-lawyering approach. For example, a recent book aimed at practicing lawyers considers conflicts of interest not from the standpoint of the professional disciplinary rules, but from the point of view of judicial decisions to disqualify lawyers from representing clients in litigation. ${ }^{5}$ Treatises on legal ethics in other

\footnotetext{
${ }^{2}$ For outstanding examples of this approach, see Donald Nicolson \& Julian Webb, Professional Legal Ethics: Critical Interrogations (Oxford: Oxford University Press, 1999); David Luban, Lanyers and Justice: An Ethical Siudy (Princeton, NJ: Princeton University Press, 1988). One noteworthy work of political philosophy is aimed at adversarial professions generally, but has obvious application to legal ethics. Arthur Isak Applbaum, Ethics for Adversaries (Princeton, NJ: Princeton University Press, 1999).

${ }^{3}$ See, for example, two excellent books on conflicts of interest, in the United States and the United Kingdom, respectively: Susan P. Shapiro, Tangled Loyallies: Conflicls of Inlerest in Legal Praclice (Ann Arbor: University of Michigan Press, 2002); Janine Griffiths-Baker, Serving Two Masters: Conflicts of Interest in the Modern Lam Firm (Oxford: Hart Publishing, 2002). I am hopeful that these books will be reviewed in a future issue of Legal Fithics.

4 David B. Wilkins, "Who Should Regulate Lawyers?", (1992) 105 Harvard Lam Reviem 799.

5 Richard E. Flamm, Lamyer Disqualificalion: Conflicts of Interest and Olher Bases (Berkeley, CA: Banks \& Jordan, 2003).
} 
jurisdictions adopt a similar perspective. ${ }^{6}$ A legal ethics course has been a mandatory part of American legal education since the 1970s, and the Lord Chancellor's Advisory Committee on Legal Education and Conduct has recommended that ethics education be similarly integrated into vocational training in the United Kingdom. Thus, the needs of legal educators for quality teaching and reference materials, as well as the demands of practitioners, will continue to drive the development of books dealing with ethical issues in the terms of authoritative legal norms.

The positive-law version of the "is it ethical?" question can be answered by careful exposition of the law governing lawyers. Frequently, however, the debate over whether something is ethical for lawyers is framed as a normative question, so that what is actually being asked is whether it is a good thing that contingent-fee financing exists, whether client confidentiality should be absolute or should yield to the interest in preventing certain kinds of harms to third parties, and so on. But as soon as the question is posed in these terms, one might reasonably ask by what slandard the normative inquiry is to be evaluated. One possibility, previously mentioned, is to employ concepts from moral philosophy, which have been sharpened in the past several decades by their application to practical problems in disciplines such as medical ethics. ${ }^{7}$ Legal ethics at its best draws not only from traditional ethical principles such as utilitarianism and Kantian deontology, but makes use of insights developed more recently by feminist, postmodern, neo-Aristotelian, and communitarian scholars. ${ }^{8}$ Some critics of this approach have recommended instead that the relevant values be located within the law itself, but they agree that lawyering is not a value-neutral exercise that is insulated from criticism in moral terms. ${ }^{9}$ An alternative foundation may be emerging, namely the use of micro-economic methods based on assumptions about the behavior of rational actors. Law and economics, as the movement is known in the United States, has swept through and colonised many disciplines, such as torts and corporate (company) law, to the point that it is difficult to do serious scholarship in these areas without either doing law and economics or mounting a sustained critique of this approach. So far law and economics has established only limited beach-heads on the island of legal ethics, ${ }^{10}$ but we can almost certainly expect future expansion. We can also expect continued publication of books from sociologists, historians,

${ }^{6}$ See, for example, G.E. Dal Pont, Lamyers' Professional Responsibility in Australian and New 'Lealand (Sydney: LBC Information Services, 1996).

${ }^{7}$ For a leading example, see Tom L. Beauchamp \& James F. Childress, Principles of Biomedical Ethics (Oxford: Oxford University Press, 5th ed., 2001).

${ }^{8}$ See, eg, Nicolson \& Webb, supra (incorporating feminist and postmodern perspectives); Walter Bennett, The Iawyer's Myth: Reviving Ideals in the Iegal Profession (Chicago: University of Chicago Press, 2001) (using narrative theory, psychology, and mythology to reconstruct idealised lawyers); Mary Ann Glendon, A Nation Under Lamyers: Hom the Crisis in the Legal Profession is Transforming American Sociely (New York: Farrar, Straus and Giroux, 1994) (building on the communitarian critique of individualism and rights-discourse); Anthony $\mathrm{T}$. Kronman, The Losl Lamyer Failing Ideals of the Legal Profession (Cambridge, MA: Belknap Press, 1993) (advocating return to Aristotelian conception of the virtuous lawyer-statesman); Rand Jack \& Dana Crowley Jack, Moral Vision and Professional Decisions: The Changing Values of Women and Men Lamyers (Cambridge: Cambridge University Press, 1989) (building on cultural feminism to critique standard models of ethical lawyering).

9 William H. Simon, The Practice of Justice: A Theory of Lawyers' Elhics (Cambridge, MA: Harvard University Press, 1998); W. Bradley Wendel, "Civil Obedience", (2004) 104 Columhia Lam Reviem 363.

${ }^{10}$ Sce, eg, George M. Cohen, "When Law and Economics Met Professional Responsibility", (1998) 67 Fordham Lam Reviem 273. 
and anthropologists, who have contributed a great deal of knowledge about how the legal profession is actually organised and regulated. ${ }^{11}$

\section{The Promise and Perils of Being Interdisciplinary.}

In the editorial inaugurating the journal, Kim Economides and Julian Webb expressed hope that Legal Elhics could help bridge the gap between academics and practitioners. ${ }^{12}$ Concerns about this gulf have been expressed on this side of the Atlantic as well, most prominently by Harry Edwards, a federal appellate judge who bemoaned the "growing disjunction" between the academy and the bar. ${ }^{13}$ Ironically, Judge Edwards objects to precisely one of the ambitions of Legal Elhics, namely the integration of perspectives from other disciplines into legal education. His fear is that academics whose foundations are in other intellectual traditions, such as economics, history, or philosophy, will be unable to produce scholarship that makes a difference to what lawyers and judges actually do in practice. These "ivory tower dilettantes" may be doing something interesting, but their concerns are not the concerns of professionals in the real world. It seems fair to read Judge Edwards' comments as an argument that any gap-bridging that occurs between university teachers and practitioners must be a one-way bridge, with the pragmatic concerns of lawyers and judges guiding the research efforts of scholars.

Judge Edwards has been accused of overstating his case, relying on anecdotal evidence, ignoring the vital role that policy analysis plays in legal reasoning, clinging to an anachronistic formalist conception of the law, and undervaluing pure research that may not pay immediate practical dividends but which may nevertheless contribute to our increased understanding of the law. ${ }^{14}$ Nevertheless, he does raise a useful point of caution. Academic discourse can become esoteric and self-referential, and its connection to the concerns of practitioners may not be immediately apparent. This is not to devalue research that is not aimed at producing work that can be digested easily by non-specialists. There is intrinsic value in increased knowledge about any subject, whether or not there is some tangible payoff. But even if there is merit in the scholarship itself, it may be unrealistic to expect it to have much interest for professionals whose daily lives are dominated by more pragmatic considerations. The lawyer's perspective is an essential one to preserve in the discourse of legal ethics, and not only for the obvious reason that lawyers know more than non-lawyers about the kinds of dilemmas they encounter in practice. The practical-minded approach of lawyers is a useful contrast to the sometimes arid, highly abstract examples one frequently encounters in moral

11 Sce, eg, Richard L. Abel, English Lawyers Betmeen Market and State: The Politics of Professionalism (Oxford: Oxford University Press, 2003); Elliott A. Krause, Death of the Guilds: Professions, States, and the Advance of Capialism, 1930 to the Present (New Haven: Yale University Press, 1996); Marc Galanter \& Thomas Palay, Tournament of Lamyers: The Transformation of the Big Lam Iirm (Chicago: University of Chicago Press, 1991).

12 Kim Economides \& Julian Webb, "The Ethical Imagination", (1998) 1 Legal Fithics 1.

1.3 Harry T. Edwards, "The Growing Disjunction Between Legal Education and the Legal Profession”, (1992) 91 Michigan Lam Reviem 35.

14 Many of these criticisms were raised in a symposium on Judge Edwards' article in the Michigan Lam Reviem. Sec, eg, Lee C. Bollinger, "The Mind in the Major American Law School", (1993) 91 Michigan Lam Reviem 2167; Sanford Levinson, "Judge Edwards' Indictment of 'Impractical' Scholars: The Need for a Bill of Particulars", (1993) 91 Michigan Lam Reviem 2010; Robert W. Gordon, "Lawyers, Scholars, and the 'Middle Ground"”, (1993) 91 Michigan Law Reviem 2075. 
and political philosophy. ${ }^{15}$ In the real world, facts are always more ambiguous and messy than they appear in the neat hypotheticals discussed in practical ethics courses. Lawyers are also better adapted than theoreticians to making judgments in non-ideal worlds, as opposed to hypothetical circumstances in which moral rules are perfectly followed. ${ }^{16}$ Finally, lawyers appreciate that moral deliberation eventually must end, and something must be done. I can recall engaging in delightful and wide-ranging conversations with the judge for whom I clerked, which would end when he said, "Okay, now do we affirm or reverse the district court?" That kind of question is one that critics who are not actually embedded in the practice of lawyering or judging have the luxury of deferring. For these reasons, the conversation about legal ethics must never become so removed from the concerns of practitioners that it fails to incorporate the lawyer's perspective sufficiently.

Several books have been published recently in a genre that Judge Edwards would presumably approve of - namely, a theoretically informed, highly sophisticated account of professional ethics that is sufficiently grounded in the world of practice to be accessible to non-specialist lawyers. These books take not only an interdisciplinary perspective, but a "bridging" perspective between the academic and practical realms. Two notable examples are Andrew Boon and Jennifer Levin's The Elhics and Conducl of Lawyers in England and Wales ${ }^{17}$ and Deborah Rhode's In the Inleresls of Fuslice: Reforming the Legal Profession, ${ }^{18}$ which is centred on the American system. They not only offer a bird's-eye view of the law, policy, and theory applicable to the practice of law, but suggest areas for further in-depth research. A slightly different, but equally promising format is the collection of essays including contributions from both academics and practitioners. Excellent volumes have appeared focusing on Australia, ${ }^{19}$ the $\mathrm{UK},{ }^{20}$ and the US, ${ }^{21}$ although in each of these cases some of the contributors have taken a trans-jurisdictional perspective.

\section{International and Comparative Perspectives.}

An obvious problem that confronts any attempt at comparisons between the rules of professional conduct governing different nations' legal practitioners is the variety of organisational structures that are encountered. The common-law world alone includes the bifurcated profession in England and Wales, the unified or "fused" professions in the US, Canada, ${ }^{22}$ and

${ }^{15}$ Dennis F. Thompson, Political Eithics and Public Office (Cambridge, MA: Harvard University Press, 1987), 8-9.

${ }_{16}$ John Rawls, A Theory of Justice (Cambridge, MA: Belknap Press, 1971), 8-9, 351.

17 Andrew Boon \& Jennifer Levin, The Eihics and Conduct of Lawyers in England and Wales (Oxford: Hart Publishing, 1999).

${ }^{18}$ Deborah L. Rhode, In the Interests of Fustice: Reforming the Jegal Profession (Oxford: Oxford University Press, 2000).

19 Stephen Parker \& Charles Sampford, eds., Legal Ethics and Legal Praclice: Contemporary Issues (Oxford: Clarendon Press, 1995).

${ }^{20}$ Kim Economides, (ed.), Elhical Challenges lo Legal Educalion and Conduct (Oxford: Hart Publishing, 1998); Ross Cranston, (ed.), Legal Ethics and Professional Responsibility (Oxford: Clarendon Press, 1995).

21 Deborah L. Rhode, (ed.), Elhics in Practice: Lamyers' Roles, Responsibilities, and Regulation (Oxford: Oxford University Press, 2000).

${ }^{22}$ William H. Hurlburt, The Self-Regulation of the Legal Profession in Canada and in Fngland and Wales (Calgary: Law Society of Alberta, 2000), at 10-11. The legal profession in Quebec has a structure familiar in civil law countries, with a profession of advocates, who represent clients in litigated matters, and notaries, who are hybrid public/private actors charged with authenticating certain transactions. 
New Zealand, ${ }^{23}$ and the hodgepodge regulatory structure in Australia. ${ }^{24}$ The situation becomes more complex when civil law systems are taken into account. Activities that must be performed by a licensed lawyer in the United States, at the risk of being deemed the unauthorised practice of law, may be undertaken in France by an avocal (for most litigated matters), specialised avocals (for appellate practice), a huissier de juslice (for execution of judgments), and of course notaries, who perform document drafting and recording functions for many essential transactions. ${ }^{25}$ And complicating matters further is the overlay of supranational regulation, such as Directives of the European Union Commission, the adoption of the Code of Conduct for Lawyers in the European Community (CCBE), and the General Agreement on Trade in Services (GATS) ${ }^{26}$ The variations among these regulatory structures may lead one to question whether there are universal norms of lawyering that can be applied across jurisdictional boundaries.

Of course, it may be possible to discuss principles of legal ethics at a sufficiently high level of abstraction that they could conceivably apply to lawyers in any national system. For example, one commentator lists four professional duties that apply to lawyers generally: independence, integrity, loyalty to the client, professional secrecy. ${ }^{27}$ This is a kind of conceptual argument, that the very notion of being a "lawyer" is constituted by having these four duties. As the saying goes, this is all well and good in theory, but in may not work in practice, for the reason that each of these principles gains meaning and content only through application to concrete practical dilemmas. Professional independence, for example, can mean many different things - independence from the client, from the state, avoidance of conflicting interests or, as the distinguished American lawyer Elihu Root put it, the ability to tell a client that "[t]he law lets you do it, but don' $t$ - it's a rotten thing to do." 28 Various national legal systems may lay different emphasis on these aspects of independence. For example, recent amendments to the American Bar Association's Model Rules of Professional Conduct prioritise a transactional lawyer's independence from the client over the lawyer's independence from the state. ${ }^{29}$ That is, they permit the reporting of confidential information to regulators or affected third parties where necessary to prevent, rectify, or mitigate certain financial losses. These amendments were motivated in large part by the US corporate scandals of 2002, which many believe were the result of the insufficient independence of professionals, such as lawyers and accountants. But there is nothing in the concept of independence that would foreclose precisely the opposite argument, that lawyers should be more independent of the state and have heightened duties of confidentiality. How much, and what

23 Dal Pont, supra, at 22-26.

24 Ysaiah Ross, Ethics in Iam: Lamyers' Responsibility and Accounlability in Australia (Chayswood, NSW: Butterworths, 3rd ed., 2001), at 75-79. Some states in Australia (such as New South Wales) maintain formal separation of the professions with a high degree of de facto fusion; other states (such as Victoria) recognise a formally fused profession with a high degree of de facto distinction; finally, some states (such as South Australia) never established a divided profession.

25 John Leubsdorf, Man in His Original Dignity: Legal Ethics in lirance (Aldershot: Ashgate, 2001), at 93-100.

${ }_{26} \mathrm{Scc}$, eg, Laurel S. Terry, "GATS' Applicability to Transnational Lawyering and Its Potential Impact on U.S. State Regulation of Lawyers", (2001) 34 Vanderbilt Journal of Transmational Law 989.

27 Carl Bevernage, "Ethics, Professional Conduct and Practice Rules in the Cross Border Practice: The Legal Profession at Crossroads," in Koen Raes \& Bart Claessens, eds., Tomards a Nem Ethical Tramemork for a Legal Profession in Transition? (Antwerp: Intersentia, 2002), 209, at 212.

${ }_{28}$ Quoted in Sol M. Linowitz (with Martin Mayer), The Betrayed Profession: Lamyering at the End of the Tmentieth Century (Baltimore: Johns Hopkins University Press, 1994), 48.

29 ABA Model Rules of Professional Conduct, Rules 1.6 \& 1.13 (as amended August 2003). 
kind of independence is essential to ethical lawyering is a mixed empirical and normative question, and one cannot answer it merely by appealing to the concept of independence at a high level of generality.

The countervailing risk, however, is thinking implicitly about professional norms in the context of one legal system, without realising that what one is doing is applying a local and contestable conception of ethics outside the context in which it developed. This is the vice of ethnocentrism, and one of the well-known risks of comparative legal scholarship. ${ }^{30}$ Overcoming ethnocentrism requires intimate familiarity with another legal system "on the ground," so to speak, with an understanding of the implicit norms of a legal culture that do so much to shape the behaviour of lawyers. Beyond this, though, it requires using categories and abstractions that are not themselves influenced by culture-specific patterns of thought. There are a few subtle and sophisticated works on comparative legal ethics, including the volume of essays collected in Lamyers' Practice $\mathbb{E}$ Ideals: A Comparalive Viem, ${ }^{31}$ but this would appear to be an area ripe for increased scholarly attention, particularly in light of the frequently observed globalisation of economic activity.

${ }^{30}$ Scc, eg, Günter Frankenberg, "Critical Comparisons: Re-thinking Comparative Law", (1985) 26 Harzard International Lam Journal 411.

31 John J. Barcelò III \& Roger C. Cramton, Lamyers' Practice $\mathcal{G}$ Ideals: A Comparatize Viem (The Hague: Kluwer Law International, 1999). 